Maurer School of Law: Indiana University

Digital Repository @ Maurer Law

2016

\title{
Legal Recognition of Same-Sex Relationships: New Possibilities for Research on the Role of Marriage Law in Household Labor Allocation
}

Deborah A. Widiss

Indiana University Maurer School of Law, dwidiss@indiana.edu

Follow this and additional works at: https://www.repository.law.indiana.edu/facpub

Part of the Family Law Commons, and the Law and Gender Commons

\section{Recommended Citation}

Widiss, Deborah A., "Legal Recognition of Same-Sex Relationships: New Possibilities for Research on the Role of Marriage Law in Household Labor Allocation" (2016). Articles by Maurer Faculty. 2376.

https://www.repository.law.indiana.edu/facpub/2376

This Article is brought to you for free and open access by the Faculty Scholarship at Digital Repository @ Maurer Law. It has been accepted for inclusion in Articles by Maurer Faculty by an authorized administrator of Digital Repository@Maurer Law. For more information, please contact rvaughan@indiana.edu. 


\section{Legal Recognition of Same-Sex Relationships: New Possibilities for Research on the Role of Marriage Law in Household Labor Allocation}

\begin{abstract}
Research comparing the relative significance of economic exchange theories and gender norms on parents' division of income-producing and domestic responsibilities often fails to consider sufficiently the role that marriage may play. This article shows that, in the United States, numerous aspects of state and federal law relating to marriage encourage spouses to specialize in distinct breadwinning and caretaking roles. Same-sex marriage offers new opportunities to assess the importance of marriage in household labor allocation decisions while controlling for gender. For any data gathered before June 2015, however, it may be distorting to characterize same-sex couples as simply "married" or "unmarried"; rather, legal recognition during the past 10 years is better conceptualized as discrete bundles of rights and tracked accordingly. This article, written by a legal scholar, provides substantive legal analysis that is integral to developing a research agenda in this area.
\end{abstract}

The incredibly rapid growth during the past decade of marriage rights for same-sex couples offers exciting new opportunities for better understanding the household labor allocation choices made by all couples. Studies of

\footnotetext{
Maurer School of Law, Indiana University, 211 South Indiana Ave., Bloomington, IN 47405 (dwidiss@indiana.edu).
}

Key Words: Child care, division of labor, gender, housework, marriage, same-sex marriage. different-sex married couples have demonstrated that wives continue to do far more housework and child care than their husbands (e.g., Bianchi, Robinson, \& Milkie, 2006; Lachance-Grzela \& Bouchard, 2010). Same-sex couples raising children together usually share child care, housework, and income-producing responsibilities far more equally, although factors such as one partner's biological connection to the child may increase specialization (e.g., Goldberg, 2010; Goldberg, Smith, \& Perry-Jenkins, 2012; Patterson, Sutfin, \& Fulcher, 2004).

This difference between same-sex and different-sex couples has been cited by academic researchers and writers in the popular press as evidence of the ongoing importance of gender roles in dividing breadwinning and caregiving responsibilities (e.g., Mundy, 2013; Solomon, Rothblum, \& Balsam, 2005). Such claims, however, overlook the fact that most published studies of labor allocation by same-sex couples raising children together rely on data that predate the availability of legal marriage. The laws governing marriage, as well as societal and personal understandings of what marriage "means," may encourage spouses to take on distinct roles. In other words, existing research finding that same-sex couples are relatively egalitarian in how they divide household responsibilities may reflect the absence of marriage rather than the effects of gender-based ideologies.

A distinct body of research assesses the role of marriage in labor allocation choices by looking at the effects of significant changes in divorce law (e.g., Stevenson, 2007, 2008) or 
by comparing cohabiting different-sex couples to married different-sex couples (Batalova \& Cohen, 2002; Baxter, 2005). This research suggests that marriage may increase specialization, but researchers also have long recognized that these findings may reflect selection effects (e.g., Brines \& Joyner, 1999). The gradual growth over the past 10 years in the number of US states permitting same-sex couples to marry, the 2013 US Supreme Court decision that resulted in federal recognition of same-sex marriages (United States v. Windsor), and the 2015 US Supreme Court decision that legalized same-sex marriage in all states (Obergefell v. Hodges) offer exciting new possibilities for research design. For the first time, it is possible to control for gender when constructing studies that assess the role that marriage may play in labor allocation decisions. This article, written by a legal scholar, provides substantive legal analysis that is integral to developing a research agenda in this area or to assessing any historical data that have been gathered on same-sex couples.

The article makes three primary contributions. First, I analyze principles of state family law, such as property distribution and alimony or maintenance regimes, as well as federal tax, Social Security, and poverty alleviation programs, to demonstrate that in the United States, numerous aspects of both federal and state law encourage spouses to take on distinct breadwinning and caregiving roles. In other words, the legal rights and incentives built into marriage law, as well as the social and individual meanings of marriage, may increase specialization. This legal analysis provides a new explanatory framework that complements and supplements existing theories regarding division of labor in the family. I recommend that theoretical and empirical work in the area consider more fully the role that marriage may play in couples' choices.

Second, I show that same-sex marriage allows the development of new testable models to assess the significance of marriage on household labor allocation. For most different-sex married couples, gender norms and marriage law will work together to encourage specialization, especially among couples with children. For same-sex couples, in contrast, the two factors will pull in opposite directions, with marriage still encouraging specialization but gender ideologies encouraging a more equal sharing of domestic and breadwinning responsibilities.
Accordingly, studies can be designed that compare different-sex and same-sex married couples raising children together, to distinguish the effects of marriage from gender differences. Of course, such models should also incorporate consideration of the spouses' relative resources, time spent at work, biological relationship to children, and other factors that can affect labor allocation.

Third, I explain the complicated and rapidly changing law that governed recognition of same-sex relationships in the United States before the 2015 court decision which struck down remaining bans on same-sex marriage (Obergefell v. Hodges). This analysis demonstrates that "married" or "unmarried" status for different-sex couples is largely a binary choice, and can be appropriately coded as such; in contrast, for same-sex couples, legal recognition over the past decade is better conceptualized as distinct bundles of legal rights whose availability turned on the state in which a couple resided, the state in which a couple was married, and the point in time when data were collected. Marriage may also facilitate recognition of both same-sex partners as legal parents of a child. Even though marriage rights are now universal in this country, researchers need to understand the past complexity to develop quantitative or qualitative studies that are sufficiently nuanced to capture and properly analyze the significance of legal recognition over the past decade. In fact, the previous patchwork quality of legal recognition may have experimental value, in that it permits the development of models that assess the effects of state marriage rights separately from federal marriage rights or the significance of civil marriage versus private marriage.

The primary objective of this article is to demonstrate how marriage rights for same-sex couples can permit new models for assessing the role of marriage in the labor allocation choices that parents, and couples more generally, make. In other words, if marriage encourages specialization, then we might find higher levels of specialization by same-sex couples now that they may marry. Such research could better explain the labor allocation choices made by both same-sex and different-sex parents.

More generally, this article seeks to encourage a greater exchange between social science literature and legal scholarship. As demonstrated here, social science research on family dynamics can be informed by deeper understanding of 
the legal import of familial relationships; equally important, legal scholarship and policy proposals can be informed by the insights into family functioning that social science can provide. For example, if research were to substantiate that same-sex married couples, like different-sex married couples, are far more likely to specialize than cohabiting counterparts are, it could dramatically change discussions about the fair distributions of assets upon divorce and the best way to accommodate work and family responsibilities within families, because it would suggest that marriage, as opposed to gender ideologies or individual choice, was playing a large role in shaping these choices.

The analysis that follows focuses on marriage law in the United States. Marriage rights for same-sex couples are evolving around the world (Pew Research, 2014; Saez, 2011). Comparisons of different-sex and same-sex couples who marry in other countries can similarly shed light on the relative significance of gender norms and any particular substantive marriage law (Jaspers \& Verbakel, 2013; Treas \& Lui, 2013). Cross-national comparisons may also provide a better understanding of the interplay of factors, particularly because the legal rights and social significance of marriage varies dramatically among nations (e.g., Fine \& Fine, 1994; Soons $\&$ Kalmijn, 2009). These possibilities are briefly discussed in the final section.

\section{Household Labor Allocation by Couples}

Many studies have suggested that same-sex couples raising children together tend to share income-producing and domestic responsibilities more equally than do married different-sex parents. Theorists have posited that this difference highlights the ongoing salience of gender. But most studies of labor allocation by same-sex couples predate the possibility of legal marriage. Accordingly, the couples studied in these two bodies of research differ in two important respects. The first, which is immediately obvious, is whether both members of the couple are the same sex. The second, far less discussed, is whether or not they are married. This section briefly reviews existing literature on labor allocation choices made by same-sex and different-sex couples, focusing particularly on research regarding parents, before discussing how same-sex marriage offers the possibility of developing new testable models that compare the relative importance of marriage and gender ideologies in the choices couples make.

\section{Different-Sex Couples}

In 1960 , only $27 \%$ of married women with children younger than age 18 engaged in paid work; by 2012, 69\% of married women with children worked for pay (US Bureau of Labor Statistics, 2013). Notwithstanding this dramatic increase in labor market participation, in different-sex couples, American married women, with and without children, still spend about twice as much time as their husbands do performing household work (Bianchi et al., 2006; Claffey \& Mickelson, 2009; Greenstein, 2000, 2009; Lachance-Grzela \& Bouchard, 2010). The gender gap in housework exists across racial-ethnic categories, although the size of the gap varies (e.g., Perry-Jenkins, Newkirk, \& Ghunney, 2013; Sayer \& Fine, 2011). It also exists across education levels, although again the size of the gap varies (O. Sullivan, 2013). Married women with children-even those working full-time-also tend to spend more time engaged in child care than their husbands do, although research has suggested that this gap may be narrowing (Bianchi et al., 2006; Gerson, 2010). However, because women on average work fewer hours for pay than men, the total number of hours "worked" by husbands and wives is relatively equal (Bianchi et al., 2006).

Specialization in distinct breadwinning and caregiving roles increases dramatically for different-sex married couples after the birth of children. New mothers often decrease their paid work hours or exit the paid labor force entirely, taking on the bulk of child-care responsibilities and increasing their share of household work, whereas fathers often increase paid work hours (e.g., Grunow, Schulz, \& Blossfield, 2012; Sanchez \& Thomson, 1997; Shafer, 2011). Immediately after a birth, increased specialization may be driven in part by women's need to recover physically from childbirth or a decision to breast-feed, as well as structural factors such as mothers' greater access to paid or unpaid employment leave (e.g., Singley \& Hynes, 2005). Different-sex married parents who adopt children tend to specialize, but less so than couples with biological children (Goldberg et al., 2012). However, even long after childbirth, married mothers continue to do more housework and child care than their husbands do 
(e.g., Bianchi et al., 2006). That said, patterns may change over the life course; parents who specialize in distinct roles immediately after a child is born may renegotiate household labor allocation as children age.

Changes in work patterns of both mothers and fathers after childbirth, as well as other factors such as employer discrimination and differences in human capital levels and job effort, help explain the wage penalty that mothers typically suffer and the premium that fathers typically enjoy (e.g., Budig \& Hodges, 2010; Killewald, 2013). Research shows that the size of fathers' premiums and mothers' penalties is generally positively related to the number of children; however, the scale of the change, at least for mothers, varies with race and earning levels (e.g., Budig \& Hodges, 2010; Glauber, 2007). Marital status is also an important factor, particularly for men-fathers enjoy a wage premium only if they are married and living with their biological children (Killewald, 2013).

Focusing on the division of labor between married or, as discussed later, cohabiting couples may omit other key parts of the larger story. Grandparents and other extended family often provide significant amounts of child care (e.g., Cherlin, 2010). Older children may care for younger children, perform housework, or contribute income (Perry-Jenkins et al., 2013). In addition, and relatedly, such analysis necessarily excludes single-parent families. Approximately $40 \%$ of children born in the United States are born to unmarried women; these rates are sharply skewed by race and class (US Centers for Disease Control and Prevention, CDC, 2013). Although approximately half of unmarried parents are cohabiting at the time of the birth, many poor and working-class mothers are unwilling to marry men whom they do not believe will be able to provide for the family economically (e.g., Edin, 2000; Edin \& Kefalas, 2005; Edin \& Lein, 1997; Gibson-Davis 2007). Many such parents state that they hope to ultimately marry, but only if - and when-both parents are on solid financial footing; for many, marriage is indefinitely deferred and the couple eventually separates (e.g., Edin \& Kefalas, 2005).

Multiple-partner fertility and blended families are also increasingly common (Cherlin, 2010), and they may affect how couples divide responsibilities (Perry-Jenkins et al., 2013). For example, housework and paid labor are shared more equally in second marriages than first marriages, although the split is still not equal (Ishii-Kuntz \& Coltrane, 1992; O. Sullivan, 1997). On the other hand, stepparents, particularly stepfathers, may be less likely to perform significant child care for stepchildren, either because of their own inclinations or because of gatekeeping by the biological parent. These distinctions may be even more pronounced for cohabiting couples who live with a child from a prior relationship of one of the partners (Monte, 2007).

Hopefully, future research will continue to deepen our understanding of the role that race, ethnicity, and social class, as well as factors such as remarriage or other blended families, may play in division of household labor. But despite these important variations, it is apparent that a gendered division of both child-care and household responsibilities remains common for different-sex married parents. There are three leading explanations in the literature. Relative resources theories suggest that whichever spouse has greater earning power, or, in some iterations, the higher level of education, will either explicitly or implicitly bargain out of doing housework (see, e.g., Thebaud, 2010, for a review). Time allocation analysis suggests that whoever spends more time doing paid work typically performs a smaller share of housework (e.g., Thebaud, 2010). Empirical evidence provides considerable support for these bargaining-based theories, although it is important to distinguish between housework, which is consistently characterized by both men and women as unenjoyable, and child care, which is often perceived by men and women as enjoyable (O. Sullivan, 2013). That said, relative resources also help explain choices regarding child care; if a couple decides to forgo or minimize use of paid child care in favor of parental caregiving, it will "make sense" for the spouse who makes less to stay home. Economic exchange theories are usually presented as sex neutral; however, because husbands typically earn more and spend more time at their paid jobs than their wives, these theories help explain the gender gap in domestic work (e.g., Coltrane \& Shih, 2010).

Relative resources or time allocation theories do not fully explain household labor allocation; a large body of research suggests that gender ideologies play an important role as well. Several studies have found that women who earn more than their husbands also perform a greater share of housework, and researchers have 
suggested that couples in which women serve as the primary breadwinner "correct" for "gender deviance" by embracing a traditional allocation of household responsibilities (Bittman, England, Sayer, Folbre, \& Matheson, 2003; Brines, 1994; Greenstein, 2000). These results, however, may be skewed by a small group of outlier men who earn nothing at all (Bittman et al., 2003; Evertsson \& Nermo, 2004), as well as by failing to differentiate among women's income levels (O. Sullivan, 2011). Additionally, many of the studies rely on data that are now relatively old, and the effect may be mitigating as gender roles become more flexible (O. Sullivan, 2011). That said, gender still seems to be at least part of the story. For example, a key determinant in household labor allocation is women's absolute earnings rather than spouses' earnings relative to each other, which may demonstrate that higher-earning women simply outsource greater amounts of domestic work (Gupta, 2006, 2007). A different study concluded that even if high-earning women do not take on additional housework, the rate of decline in their share of housework is less dramatic than pure economic theories or autonomy theories would predict (Killewald \& Gough, 2010).

Class, educational level, race, and ethnicity may interact with gender ideologies in ways that help explain the relative importance of economic bargaining as compared to gender norms in household labor allocation (Usdansky \& Parker, 2011). For example, some work suggests that poor and working-class women who earn a significant share of household income and provide the bulk of child care and household labor tend to perceive this allocation as "fair" because they retain traditional gender ideologies, or they seek to be relieved from some of their breadwinning responsibilities to further specialize in domestic work (Goldberg \& Perry-Jenkins, 2004; Perry-Jenkins \& Folk, 1994). Middle-class and professional women, in contrast, typically seek a more egalitarian split of both kinds of responsibilities (Usdansky \& Parker, 2011). Gender ideologies may also differ among racial-ethnic groups in ways that shape the division of labor (e.g., Glauber \& Gozjolko, 2011; Sayer \& Fine, 2011).

Researchers have also begun to explore more systematically the way larger structural forces, such as the organization of workplaces or social expectations, may help explain the persistent gender gap (see Noonan, 2013, for a review).
The legal incentives and benefits of marriage, discussed later, are likewise structural factors encouraging specialization. Importantly, gender ideologies often underlie such structural factors. For example, seemingly neutral employment policies, like the standard 40-hour workweek or the availability of mandatory overtime, reflect and privilege gendered ideologies that assume that (male) workers have support from (female) partners who can handle nonwork family responsibilities (Albiston, 2009; Williams, 2000). And the marriage laws discussed in the following sections were originally sex-specific obligations: husbands were legally required to provide economically for their wives, and wives were legally required to provide domestic support (Widiss, 2012). In a series of decisions during the 1970s, the US Supreme Court held that such sex-based distinctions were generally unconstitutional. Marriage and benefits laws were subsequently reformed to make support obligations largely sex neutral, but they continue to encourage specialization. Structural factors, in turn, may perpetuate gendered ideologies that encourage separate roles for men and women.

Most existing research on relative resources, time allocation, or gender ideologies does not assess the extent to which marriage may be a confounding variable. There is, however, a distinct body of research that indirectly addresses the significance of marriage law by studying whether reform of divorce law changes couples' labor allocations or women's labor force participation. Studies have found, for example, that the advent of no-fault divorce in the United States, which functionally permits unilateral divorce, decreases even newlywed couples' willingness to specialize and to invest in marriage-specific capital (Stevenson, 2007). No-fault divorce has also been shown to increase labor participation rates by women (Chiappori, Fortin, \& Lacroix, 2002; Stevenson, 2008). This work uses state-based variation in divorce laws to help isolate the effect of legal reform from larger social trends-such as the general growth in women's labor force participation - that also led to decreased specialization. Similar results have been found in other countries that likewise have liberalized divorce rules (Bargain, Gonzalez, Keane, \& Ozcan, 2012). Some studies have suggested that different property division regimes also affect the labor allocation choices couples make (Chiappori et al., 2002; Gray, 1998), although other work has questioned 
this conclusion (Stevenson, 2008). In general, liberalization of divorce law seems to decrease specialization and increase women's labor force participation, presumably because it decreases the extent to which marriage provides security for spouses who specialize in domestic work.

Finally, there is a body of research that compares different-sex married couples to different-sex cohabiting couples. Several studies have found that cohabiting couples, on average, share domestic and income-producing work more equally than married couples, even after controlling for income and other relevant factors (e.g., Batalova \& Cohen, 2002; Baxter, 2005; Matouschek \& Rasul, 2008; Perry-Jenkins et al., 2013). Most work comparing cohabiting and married couples has not examined parental status specifically, although some control for children. As Perry-Jenkins et al. (2013) has pointed out, it is therefore possible that studies may have "masked" the extent to which the presence or absence of children affects the division of labor for cohabiting couples. Nonetheless, these studies could support a hypothesis that marriage encourages specialization. However, as researchers have noted, they may also reflect selection effects, in that different-sex couples who opt for long-term cohabitation without marriage may be more autonomous or egalitarian than those who marry (e.g., Brines \& Joyner, 1999).

As discussed more fully in the following sections, same-sex marriage offers a different window for assessing the significance of marriage law, and one that can help control for this potential selection bias. Recent work has also suggested the importance of recognizing variation within marital and cohabiting unions, particularly since in a growing number of countries (and US states) cohabitors can make legal commitments to each other that are similar to those of marriage, and because many cohabiting couples intend to, and subsequently do, marry (Poortman \& Mills, 2012). This insight is helpful when considering same-sex couples, who have long used private contract law and wills to replicate aspects of marriage law.

\section{Same-Sex Couples}

The 2010 census suggested that there were approximately 646,000 same-sex couples living together in the United States. Demographers believe that, as of 2011, approximately 114,000 same-sex couples were married, with 76,000 living in a state that recognized their marriage and 38,000 living in a state that did not (Gates, 2013a). ${ }^{1}$ At that time, there were approximately 108,000 additional same-sex couples in civil unions or registered domestic partnerships. The number of states permitting same-sex couples to marry expanded extraordinarily rapidly in recent years, even prior to the 2015 US Supreme Court decision that made marriage rights universal (Obergefell v. Hodges). Analysis of data gathered in spring 2015, before the Supreme Court's ruling, suggested that, by that time, there were approximately 390,000 married same-sex couples, out of a total of nearly 1 million same-sex couples, with about $16 \%$ living in states that did not recognize their marriage (Gates \& Newport, 2015). The number of married couples has almost certainly risen further now that couples may marry in any state.

Using 2010 census data, Gates (2013b) estimated that approximately one-fifth of same-sex couples $-31 \%$ of couples who identified themselves married and $14 \%$ of couples who identified themselves as unmarried-were raising children together. Rates of child rearing were much higher for lesbian couples than for gay male couples. Although public discourse on same-sex couples typically focuses on couples who have jointly planned to parent through adoption, artificial insemination, or surrogacy, demographers believe that the majority of children currently being raised by same-sex couples were conceived in prior heterosexual relationships (Gates, 2011; Goldberg \& Gartrell, 2014; Moore \& Stambolis-Ruhstorfer, 2013). Adoption is most prevalent among White and highly educated couples; same-sex couples that include racial minorities and couples with lower levels of education are more likely to be raising children from prior heterosexual relationships (Gates, 2011).

A growing body of literature examines household labor allocation by established same-sex couples who are raising children together. Numerous studies have found that same-sex

\footnotetext{
${ }^{1}$ These estimates are based on inferences from the way in which respondents answered questions regarding other household members, and may reflect personal conceptions of relationships that differ from formal legal categories (Gates, 2010). In 2014, the US Census began collecting and releasing data on same-sex married couples specifically.
} 
couples, both male and female, typically share child-care responsibilities far more equally than different-sex couples do (Biblarz \& Savci, 2010; Goldberg et al., 2012; Goldberg \& Perry-Jenkins, 2007; Patterson, 2000; Patterson et al., 2004; M. Sullivan, 2004). Same-sex couples raising children together typically share housework relatively equally as well (e.g., Goldberg et al., 2012; Patterson, 1995; M. Sullivan, 2004). And studies suggest that both partners in lesbian relationships tend to decrease their hours of paid work at least somewhat if raising a child, in sharp contrast to different-sex couples, where husbands often increase paid work time following the birth of a child (Antecol \& Steinberger, 2011; Goldberg \& Perry-Jenkins, 2007).

Studies also suggest that many same-sex couples state that their ideal division is an equal split of income-producing and domestic responsibilities (e.g., Chan, Brooks, Raboy, \& Patterson, 1998; Patterson et al., 2004; M. Sullivan, 2004). Such preferences help shape choices. For example, Patterson et al. (2004), in a study of lesbian couples raising children together, assessed the relative importance of hours in paid employment, educational attainment, and preferences regarding allocation of child-care responsibilities and concluded that "the most powerful predictor of the second mother's participation in childcare was her own ideas about the division of labor" (p. 188).

This is not to say that same-sex couples raising children together do not specialize at all. For example, a large-scale study of lesbian couples found a much bigger gap in work hours between primary and secondary earners in couples raising children together than in couples without children (Antecol \& Steinberger, 2011). A study of gay male couples raising adopted children found that more than half included a partner who worked part-time or stayed home full-time to provide child care, and that the partner staying home often increased his share of the housework (Goldberg, 2012). Several studies have suggested that biological relationship to a child is a factor in the division of household responsibilities for lesbian couples (see Goldberg, 2010). In part, this may be because biological mothers have greater access to parental leave or are breast-feeding (Goldberg et al., 2012; Goldberg $\&$ Perry-Jenkins, 2007). However, some studies have found that biological mothers continue to take on greater responsibilities for child rearing even after the time when such factors are pertinent (e.g., Downing \& Goldberg, 2011), that they take on greater responsibilities for "feminine" housework (Goldberg et al., 2012), and that nonbiological mothers spend more time in paid work (Patterson, 1995). Other studies have not found that biological connections make a difference (e.g., Chan et al., 1998; M. Sullivan, 2004). ${ }^{2}$

Legal relationship to a child may also be an important factor. In some states (even some states where same-sex couples could not marry before the 2015 Supreme Court decision), both members of a same-sex couple may adopt a child, whereas in other states, only one may (Joslin, 2014). A legal parent will generally have greater access to leave from employment and may be treated by third parties as the "real" parent. This may increase the likelihood that the legal parent does a greater share of child care. The increased availability of marriage rights will likely mitigate this issue because married couples can generally jointly adopt. Additionally, some courts have applied the marital presumption-pursuant to which a husband is presumed to be the legal father of any children born to his wife- to same-sex couples, although others have not (NeJaime, 2014).

Just as in different-sex families, blended families that include children from prior (heterosexual or same-sex) relationships may share responsibilities differently than couples raising jointly planned children do. For example, a study of Black lesbian women with children from prior heterosexual relationships found that they were unlikely to share equally child-care responsibilities or to pool financial resources with a new lesbian partner (Moore, 2008). ${ }^{3}$ Future work on labor allocation by couples

\footnotetext{
${ }^{2}$ As noted already, in heterosexual relationships, mothers generally suffer a wage penalty and fathers typically enjoy a wage premium (although the size of the premium and penalties vary with race, income, family status, and other factors). It is not clear how such trends would operate for same-sex couples. For example, does a nonbiological lesbian mother suffer a wage penalty like a biological mother typically does? Or does she enjoy the wage premium that fathers typically receive? The extent to which such premiums or penalties exist for members of same-sex couples could either encourage or discourage specialization into distinct caregiving and breadwinning roles.

${ }^{3}$ Existing literature on household labor allocation tends to present domestic work - both child care and housework-as dichotomous to breadwinning. Moore's (2008) work, by
} 
raising children together should further probe how different paths to family formation may affect couples' choices.

Moore (2008) also has pointed out that much existing research on labor allocation by same-sex couples focuses on White, middleor upper-class, highly educated couples. As discussed earlier, studies of different-sex couples have suggested that educational attainment levels, social class, race, and ethnicity intersect with gender ideologies in ways that help determine the allocation of household labor. Future research should further investigate whether and how such factors affect labor allocation by same-sex couples. This research may also dovetail with consideration of family formation patterns, which also vary by race and class (Gates, 2011).

Studies of childless same-sex couples, or studies that do not explicitly distinguish between parents and nonparents, have likewise found relatively equal sharing of housework (e.g., Kurdek, 2007; Peplau \& Fingerhut, 2007; Solomon et al., 2005). Again, results are not uniform. An older, qualitative study of 52 long-term gay and lesbian couples without children found quite high levels of specialization (Carrington, 1999).

Same-sex couples often consciously "do"- and "undo"- gender in different ways from heterosexual couples (e.g., Gabb, 2005; Goldberg, 2013; M. Sullivan, 2004). Some same-sex couples may feel pressured to conform to the expectation of equal sharing. For example, Carrington (1999) suggested that he found high levels of specialization in part because he relied on personal observation of the couples rather than self-reports, which can be subject to distortion. And couples who specialize often distinguish their decision to do so from traditional heteronormative patterns (e.g., Goldberg, 2012; M. Sullivan, 2004). Relatedly, the partner who goes "against" gender norms may express ambivalence about doing so; for example, Berkowitz (2011) reported that in interviews, gay fathers struggled with "sacrificing their role as provider," even as they also embraced certain "maternal" instincts (p. 516). Goldberg and Gartrell (2014) also suggested that researchers "have tended to downplay"

contrast, describes biological mothers as highly protective of both breadwinning and caretaking roles. Future work should explore this dynamic more extensively. the extent to which same-sex couples display tendencies to specialize because of the "dominant mantra" that same-sex couples share responsibilities more equally (p. 66).

Citing the many studies concluding same-sex couples tend to split domestic and income-producing work relatively equally, a few academic researchers and writers in the popular press have claimed that same-sex couples may serve as an example for different-sex couples struggling to share household responsibilities (e.g., Belkin, 2009; Mundy, 2013; Parker-Pope, 2008; Solomon et al., 2005, p. 572). They also suggest that the differences in typical labor allocation between same-sex and different-sex couples highlight the importance of gender relative to economic factors in couples' choices. This is possible-but the conclusion is premature.

The vast majority of published studies of labor allocation by same-sex couples in the United States rely on data that predate the possibility that the couples are legally married or in any other formal state-recognized relationship. Even studies that have collected data after the advent of marriage have often failed to consider the extent to which legal frameworks-or the absence thereof-may play a role in the choices same-sex couples make. ${ }^{4}$ Others have identified it as an issue that warrants further study (e.g., Badgett, 2001; Oswald \& Kuvalanka, 2008), but until recently, it was difficult to do so. The advent of same-sex marriage thus offers significant new opportunities to better understand labor allocation by all couples. Drawing on my background as a legal scholar, in the next sections I identify aspects of state and federal law that encourage married couples to specialize. The concluding sections provide legal

\footnotetext{
${ }^{4}$ One partial exception is Solomon et al. (2005), which compares same-sex couples who formed civil unions in Vermont to their married heterosexual siblings and to same-sex couples not in civil unions. Like earlier work, this study found that same-sex couples divided housework responsibilities far more equally than different-sex couples, and it did not find that civil union status affected allocation of household work. However, $80 \%$ of the couples did not live in Vermont and, as explained more fully in the text below, this means that most received no legal benefit from forming a civil union. Additionally, a much higher percentage of the married heterosexual couples had children than did the lesbian or gay couples, both in and not in civil unions; this probably explains at least part of the disparity in likelihood to specialize.
} 
analysis that can be used to develop models that appropriately capture the complexity of legal status for same-sex couples and the role it may play in the choices couples make.

\section{State Marriage Law Protecting DePENDENT SPOUSES}

In the United States, marriage has traditionally been governed primarily by state law, although, as discussed more fully in the following section, numerous federal rights and benefits are premised on marriage. Individual states determine the rules for who may marry, as well as many of the rights, benefits, and obligations of marriage. Most important for household labor allocation, state law governs how property is distributed upon divorce, the availability of alimony or maintenance payments to a former spouse, and the custody of children. State law also primarily controls child support, although the federal government has played a key role in standardizing certain provisions. Although not the focus of this article, state law also generally controls distribution of property upon death, as well as compensation for the death or injury of a spouse; who is authorized to make decisions regarding health care; whether and when one member of a couple can be responsible for repaying debts incurred by the other; and numerous other subjects.

As noted already, historically, marriage law enforced the separate spheres ideology by imposing distinct obligations on husbands and wives. Although most marriage law is now sex neutral, it continues to mandate in various ways that a wage-earning spouse support a dependent spouse during and after a relationship. In almost all states, the default rule is that any income earned by either member of the couple during the marriage - and property accumulated with that income-is marital property and subject to equitable distribution upon divorce (e.g., Gregory, Swisher, \& Wilson, 2005; Oldham, 2008). In making such distributions, courts are instructed to consider a variety of factors, including the extent to which one spouse's noneconomic contributions, such as caring for children or performance of domestic tasks, contributed to the accumulation of property and the relative earning potential of each member of the couple (e.g., Gregory et al., 2005; Widiss, 2012). There are also a few states in which such property is "community" property that is split 50-50 upon divorce (e.g., Gregory et al., 2005; Oldham, 2008), as well as a few states in which even property that was individually owned before the marriage or inherited by an individual during the marriage is subject to equitable distribution (e.g., Gregory et al., 2005). In short, in all states, upon divorce, a dependent spouse will typically receive a significant share of the income earned during the marriage by a breadwinning spouse, as well as any property acquired with that income.

State law also permits courts to award maintenance or alimony payments to a dependent spouse following a divorce, although in some states such awards are time limited. Again, courts are generally instructed to consider whether a spouse has minimized paid labor to support the family through domestic work such as child rearing or homemaking (Widiss, 2012). And state law provides that a parent who retains custody of children will receive child support from the other parent, generally until the children reach the age of majority or complete certain levels of education (Gregory et al., 2005). Individuals may use prenuptial or postnuptial contracts to depart from the legal defaults regarding property allocation or maintenance, but such contracts are relatively rare, and courts are empowered to scrutinize such contracts for procedural and, in some states, substantive fairness (Gregory et al., 2005).

Divorce law does not offer dependent spouses a comprehensive safety net. Indeed, as noted already, dramatic changes in state divorce law that occurred in the 1970s and 1980s-most notably permitting unilateral divorce and limitations on alimony awards-have been shown to decrease specialization by married (different-sex) couples (Stevenson, 2007, 2008). The important thing to recognize, however, is that divorce law offers far more protection to a dependent spouse than does the law governing cohabiting couples who are not in a state-recognized legal status.

In almost all states, the legal default for cohabiting couples is that income earned during the relationship remains separate income, and that property bought with such income is separate property (e.g., Bowman, 2004). In other words, in the absence of a private legal contract, a member of a cohabiting couple who curtails labor market participation to provide domestic support to a household will generally receive no share of income earned by the 
other partner or property purchased with that income. An unmarried individual may claim child support from the biological parent of her or his child, but studies find that never-married mothers typically collect less child support than do comparably situated mothers who were married to the fathers of their children when they were born (e.g., Case, Lin, \& McLanahan, 2003). A member of a same-sex couple may have a particularly difficult time claiming child support from a former partner who is neither biologically nor legally related to a child.

\section{Federal “Marriage” LaW Encouraging SPECIALIZATION}

The federal US government does not officially have a "marriage" law, in that marriages are granted exclusively by the states. But there are more than 1,000 federal statutes that use marriage as a factor in determining rights, benefits, and obligations (US General Accounting Office, 2004). Although federal benefits that flow from marriage apply to numerous areas of life, this discussion focuses on several aspects of federal law that relate directly to household labor allocation and encourage couples to specialize into breadwinning and caregiving roles.

Federal income tax policy provides an incentive for married couples to specialize. If one spouse earns all, or a significantly larger portion, of the household's total income, the married couple receives a "marriage bonus"- that is, they pay less in taxes than they would if they were single. In contrast, at middle- to upper-income brackets, a married couple in which each spouse earns about the same amount in paid labor will pay a "marriage penalty"- that is, they pay more in taxes than they would if they were single (McMahon, 2011). These tax benefits are available regardless of whether the nonearning or low-earning spouse is caring for children or engaging in other domestic work, but they have the effect of encouraging specialization. Additionally, if both spouses work for pay, they pay taxes on the income each earns, including most income used to purchase child-care services (a small deduction or credit is available) or other household services. But if a spouse forgoes paid labor to care for children or perform other domestic work, the couple does not pay taxes on the imputed value of that work (McCaffery, 1997).
Studies have generally concluded that married women's participation in the labor market is highly responsive to the incentives embedded in the tax code (see Keane, 2011, for a review). And Fisher (2013) used variation among state income tax systems to show that marriage incentives and penalties have at least small effects on the probability of marriage relative to unmarried cohabitation. Moreover, it is easier for married couples than unmarried couples to specialize into distinct caregiving and breadwinning because many employers make health-care benefits available to the spouse of an employee; under federal tax law, the couple does not pay any tax on this benefit. Even now that the Affordable Care Act has increased access to individual health care, many families find coverage under an employer-sponsored plan to be preferable.

Social Security and Medicare likewise provide incentives to specialize. Dependent spouses are eligible to receive spousal Social Security benefits-generally $50 \%$ of the breadwinning spouse's benefits-that supplement the breadwinning spouse's own benefits (Martin, 2012). Dependent spouses may also qualify for Medicare benefits on the basis of their spouse's employment. These "spousal" benefits are also available to former spouses after a divorce, so long as the marriage lasted at least 10 years.

Spousal benefits are rarely claimed by couples with relatively similar earning histories, because in such marriages, each spouse's own benefits exceed the available spousal benefit. But for couples with disparate earning histories, they can be quite valuable. A married couple with a sole breadwinner earning $\$ 44,600$ (the national average wage) will likely pay about $\$ 500,000$ in total lifetime payroll taxes and receive about $\$ 1.2$ million in total lifetime benefits; a single wage earner earning that same $\$ 44,600$ will pay exactly the same amount in payroll taxes, again about $\$ 500,000$, but receive only about $\$ 650,000$ in total lifetime benefits (Steuerle \& Quakenbush, 2012). In this way, the Social Security tax base subsidizes benefits for individuals who have not earned income on their own, so long as they are married to a spouse who has. Like the tax provisions discussed earlier, these benefits flow from spouses having very disparate lifetime earnings, not explicitly from specialization into breadwinning and caregiving roles, but again, like the tax provisions, they encourage specialization. And although the policy is now sex neutral, a recent article found 
that $99 \%$ of recipients of Social Security spousal benefits are women (Figinski, 2011).

Two of the primary federal programs that provide support for low-income Americans also encourage specialization into breadwinning and caregiving roles. Welfare is generally available only for families with dependent children, and since 1996, it has included work requirements. In single-parent families, this means that the parent (generally the mother) typically must work outside the home or engage in authorized education activities. But in most states, married couples who are eligible for assistance can meet their work requirements so long as either spouse works sufficient hours. Since additional income would easily push even a quite poor family over the income-eligibility threshold, and since the imputed value of providing child-care services or other domestic work is not counted as income, it will be in many families' interest to specialize (Zatz, 2009).

The earned income tax credit (EITC) likewise determines eligibility on the basis of household income, with identical or almost identical standards applying to single-parent and two-parent households, again providing an incentive for married couples to specialize (Acs \& Maag, 2005). ${ }^{5}$ Indeed, although the EITC has been shown to increase single mothers' employment, it decreases married mothers' employment (Bar \& Leukhina, 2009; Eissa \& Hoynes, 2004). Individuals may also weigh the effect that marriage would have on these benefits when deciding whether to marry; studies have shown that increases in the EITC, which could be lost if an individual marries, are associated with at least small declines in marriage rates, again where consideration of variation among states in how they have implemented these federal laws can help control for larger cultural or policy changes (e.g., Herbst, 2011).

\footnotetext{
${ }^{5}$ Generally speaking, the EITC's phase-out region creates marriage penalties - or, as noted in the text, encourages specialization among married couples with one spouse dropping out of or minimizing labor market participation to provide domestic work. But, because the EITC considers the number of children within a family, as well as the income of the parents, for certain couples, it may encourage marriage or provide marriage benefits. For example, because of the way the phase-in is calculated, if an extremely low-income individual with no children marries an extremely low-income individual with one child, they may receive a higher total EITC credit than they would if they each filed as single individuals (Herbst, 2011).
}

Thus, across various income levels, the combination of federal benefits and state laws discussed in this section and the previous section may encourage married couples to specialize into breadwinning and caregiving roles.

\section{Legal Recognition of SAme-SeX RELATIONSHIPS}

The rapid growth over the past 10 years in marriage rights in individual states, the 2013 US Supreme Court decision that led to federal recognition of same-sex marriages, and the 2015 US Supreme Court decision that held that all remaining state bans on same-sex marriage are unconstitutional, make it possible to develop new models that assess the role that marriage plays in labor allocation decisions. This section explains the evolution of legal recognition of same-sex relationships in the United States to assist researchers in developing qualitative or quantitative research in this area. It summarizes a series of legal developments that I have discussed in recent articles published in law reviews (Widiss, 2014; Widiss \& Koppelman, 2015). Marriage rights are now universally available in the United States. Thus, for data gathered after June 2015, the comparison between same-sex and different-sex married couples is quite straightforward because they are governed by the same combination of federal and state laws. However, for any data gathered before the Supreme Court's decision in Obergefell v. Hodges (2015), researchers may need to determine the scope of legal rights available at the time data were collected, as well as any changes that might have occurred between waves in longitudinal studies.

In 2004, Massachusetts became the first US state to permit same-sex marriage. Initially, the pace of expansion was quite slow. As late as July 2011, only six states and the District of Columbia permitted same-sex marriage. The rate of change increased dramatically after 2013. By January 2015, when the Supreme Court agreed to hear the Obergefell case, 35 states and the District of Columbia permitted same-sex couples to marry. Additionally, beginning with Vermont in 2000, 14 states created civil unions or domestic partnership statuses that provided all of the state-level benefits and obligations of marriage. Many couples who entered into one of these alternative statuses have now married; in some states, alternative statuses were 
automatically converted to marriages. However, some individuals in such alternative statuses may opt to remain unmarried, or they may no longer have the mental capability to marry (Widiss \& Koppelman, 2015).

Until June 2013, even lawfully married same-sex couples were not recognized as "married" for federal purposes. This was pursuant to a federal statute, the Defense of Marriage Act (DOMA), which defined marriage for the purpose of all federal laws, regulations, and policies as only between a man and a woman. In June 2013, in United States v. Windsor, the US Supreme Court held that this portion of DOMA was unconstitutional. After that decision, same-sex couples who were married and who resided in a state that recognized their marriage were treated like different-sex married couples under federal law. Same-sex couples who were lawfully married but lived in a state that did not recognize their marriage received most, but not all, federal rights and benefits of marriage. This is because some federal statutes and policies looked to whether a marriage was valid in the place where it took place (known as a place-of-celebration rule), and some federal statutes and policies looked to whether a marriage was recognized as valid in the state where a couple resides (known as a domicile rule) (Widiss, 2014).

In terms of the federal policies previously discussed, which particularly encourage specialization, tax laws, including the EITC, used a place-of-celebration approach, meaning that same-sex married couples were treated as married even if they lived in states that did not recognize their marriage (US Department of the Treasury, 2013). Social Security, however, used a domicile approach, meaning that out-of-state marriages were not recognized (US Social Security Administration, 2014). As of August 2015, couples in state-recognized civil unions or domestic partnerships are generally not treated as "married" for federal purposes (Widiss \& Koppelman, 2015). However, couples in such alternative statuses are recognized for Social Security purposes, because the relevant statute explicitly covers nonmarital relationships that provide a right to inherit intestate.

The rapid evolution of legal rights makes it essential for researchers to use nuanced tools to assess the "legality" of couples' relationships and to be sensitive to the fact that this may change over longitudinal studies, even if a given couple takes no affirmative steps to change their status. For example, Solomon et al. (2005) collected data on couples who formed civil unions in Vermont during the first year that it was permitted, 2000-2001, and the surveys themselves were sent out before 2004. The researchers noted that only $20 \%$ of the couples in the sample resided in Vermont and that the couples came from a wide variety of states across the country (Solomon et al., 2005). At that time, no other state recognized Vermont's civil unions. Accordingly, at the point that the initial study was conducted, for the vast majority of couples studied, forming a civil union may have held personal or social significance, but it did not accord legal rights under state or federal law. That would no longer be true. Vermont now permits marriage and has converted its civil unions into marriages; as of 2015, all states should recognize these marriages. Furthermore, until 2013, the couples in the study were categorically denied federal recognition of their relationship; since 2013, however, couples who have since married will have received most federal rights that flow from marriage. ${ }^{6}$ Therefore, longitudinal studies of this and other similar cohorts that consider the salience of legal status should not only code for initial legal status but also track changes over time, considering both changes in the legal environment and any affirmative changes (e.g., marriage, divorce) that the couple may have made.

\section{Nongovernmental Entities, Private Contract Law, and Private Ceremonies}

The foregoing sections discuss the legal significance of marriage under state and federal law. Many private enterprises use marriage as a bright-line rule for determining whether two individuals should be treated as members of a "family." For example, employers often provide a range of benefits to spouses of employees. Even before any state permitted same-sex couples to form a legal union, private enterprises generally could choose to treat committed same-sex couples as "married," albeit sometimes with tax consequences.

\footnotetext{
${ }^{6}$ Between 2013 and 2015, couples who were married but lived in states that did not recognize their marriage were not recognized as married under a few federal statutes, including the Social Security Act and, for much of this time period, the Family and Medical Leave Act (Widiss \& Koppelman, 2015).
} 
With the advent of state-recognized same-sex marriage, this became much more common. In the years leading up to the Obergefell decision, most employers and other businesses located in states that recognized same-sex marriage, and some employers in states that did not recognize same-sex marriage, treated same-sex spouses the same as different-sex spouses. Since 2013, employers with pension plans covered by the Employee Retirement Income Security Act (ERISA), a federal law, were required to recognize all legal same-sex marriages, regardless of state of residence (US Department of Labor, 2013). Now that marriage rights are universal, private entities should generally recognize all same-sex marriages (although a few employers and other businesses are currently lodging religious objections to recognizing same-sex marriages).

Couples may also create some of the benefits and the security that marriage provides through private contracts or wills. The willingness of couples to commit to such rights, and the extent to which they have done so, may affect the likelihood that they specialize. And long before any states recognized same-sex marriage, some same-sex couples chose to "marry" each other in religious or nonreligious wedding or commitment ceremonies. Such ceremonies do not provide legal rights, but they may be an important marker of commitment. This too may encourage specialization, in that it may make it more likely one member of the couple will trust his or her partner to provide for the family financially, invest in a partner's education, or otherwise plan for the long term as a collective rather than as two distinct individuals.

\section{New Directions for Research: Disaggregating EfFects of Specialization Bias in Marriage Law From Gender, ECONOMIC EXCHANGE, AND OTHER EXPLANATORY FACTORS}

For the majority of different-sex married couples, relative resources, time allocation, gender norms, and marriage law will mutually reinforce one another to encourage the husband to shoulder primary or exclusive breadwinning responsibilities and the wife to take on primary or exclusive caregiving responsibilities. For same-sex married couples, marriage law will likewise encourage specialization. At least for many same-sex couples, relative resources or time allocation will also encourage specialization. But gender norms could well pull in the opposite direction-a choice to specialize will mean that one member of the couple is going "against" gender norms. This is likely true, even though it is also important to recognize that gender identity may be experienced and performed differently in same-sex couples than in different-sex couples (Goldberg, 2013). This reality, along with the recent variability in legal rights available to same-sex couples, offers rich possibilities for designing research that can disaggregate the various factors that shape labor allocation decisions for both same-sex and different-sex couples. This section lays out several comparisons that could be fruitful.

Before discussing potential juxtapositions of same-sex and different-sex couples, it is essential to emphasize that any research in this area needs to be sensitive to the complex interplay of legal structures discussed in the previous sections. Until June 2015, labels such as "married" or "unmarried" did not transfer well to same-sex couples. A same-sex couple who indicated on a survey conducted in 2014 that they were "married" might have meant that (a) they were legally married and resided in a state that recognized the marriage, (b) they were legally married but resided in a state that did not recognize the marriage, (c) they were members of a civil union or domestic partnership that provided full spousal-rights, and they lived in a state that recognized it (but would not have received federal recognition), or (d) they had had a private wedding or commitment ceremony but no legal union.

Further complicating the matter, a couple in several of those categories could just as readily state that they were "unmarried," as could couples with civil unions or domestic partnerships that provided them partial marital rights. Gates (2010), analyzing 2010 census data, estimated that $71 \%$ of same-sex couples who identified a partner as "husband" or "wife" in the census were legally married (with about two-thirds living in a state that recognized their marriage and one-third living in a state that did not); $15 \%$ were in civil unions or registered domestic partnerships; and $14 \%$ were not in a legally recognized relationship. For same-sex couples living together who identified as "unmarried," 79\% were not in a legally recognized relationship, but $17 \%$ were in civil unions or domestic partnerships and $4 \%$ were legally 
married (but likely answered "unmarried" because at that time the federal government, and in some instances, their home state, did not recognize the marriage) (Gates, 2010). Moreover, "unmarried" same-sex cohabitors are far more likely than different-sex cohabitors to have created marriage-like rights through private contract law, and key federal policies, as well as third-party nongovernmental entities, may have treated a couple with an out-of-state marriage as "married" even if their home state did not recognize it.

Thus, it would be difficult to make meaningful conclusions regarding the significance of legal recognition from any historical data set that simply recorded whether a same-sex couple was "married" or "unmarried." Rather, researchers need to consider (if possible) a far more detailed assessment of this constellation of factors-that is, whether the couple had a legally recognized relationship; if so, whether it received full or partial state recognition, and whether it received full or partial federal recognition; or, if they do not (or did not) have a legally recognized relationship, whether the couple had created obligations through private contract law or wills, and whether the couple has celebrated their union in a private ceremony. ${ }^{7}$ Longitudinal studies likewise need to track the extent to which a couple's legal rights may evolve even if their "status" has not changed, reflecting, for example, a change in the willingness of a home state to recognize an out-of-state union or the 2013 change in federal law regarding recognition of existing same-sex marriages.

Bearing this complexity in mind, there are several fruitful lines of potential research. First, comparisons of different-sex and same-sex married couples can help isolate and distinguish the work of gender norms and identity from marriage in encouraging specialization. The most straightforward approach would be to simply compare same-sex and different-sex married couples. This comparison will be most robust if it is based on data gathered after June

\footnotetext{
${ }^{7}$ Oswald and Kuvalanka (2008) propose a typology distinguishing between relationships that are not legalized at all; informally-recognized relationships; institutionally-recognized relationships; and "full legalization" (which at the time, before Windsor, still did not include federal recognition). The law has changed significantly since 2008, meaning researchers should consider different categories as explained in the text.
}

2015. Both state and federal governments have moved quickly to implement Obergefell; thus, for the first time, same-sex couples nationwide have full state and federal marriage rights. For data gathered between summer 2013 and summer 2015, same-sex married couples living in states that recognized their marriages were comparable to different-sex married couples, but same-sex married couples living in states that did not recognize their marriages lacked some key rights and benefits.

Since existing research suggests that both same-sex and different-sex couples are more likely to specialize when raising children together, it would be important for any such comparisons to consider the presence or absence of children. Furthermore, even if studies focus exclusively on parents, it may be important to consider family formation. For example, same-sex couples raising jointly planned children (whether adopted or conceived through assisted reproductive technology) are probably most appropriately compared to married couples raising joint children, whereas same-sex couples raising children from a prior heterosexual relationship of one of the partners might more appropriately be compared to different-sex blended families. Researchers could of course match family form even more precisely, such as comparing married different-sex adoptive parents to married same-sex adoptive parents (cf. Goldberg, 2012). Within this group, researchers might also want to compare male same-sex couples to female same-sex couples, which could reveal interesting distinctions in how gender operates in conjunction with the specialization incentives of marriage law (Goldberg, 2013).

A second research objective could be to distinguish the effects (if any) of federal marital benefits and obligations from those of state law. As discussed earlier, although state marriage law is structured to offer some protection for a dependent spouse (and far more protection than a dependent cohabitor receives), in most respects it does not actually encourage spouses to take on specialized roles in marriage. By contrast, several aspects of federal law incentivize specialization. It is impossible to assess the extent to which these two bodies of law may have differential effects with respect to different-sex couples because in almost all circumstances marriage under any state's law automatically qualifies (and always has qualified) couples for federal marital benefits. But that has not been 
true for same-sex couples. Thus, if historical data were available, a study could compare labor allocation decisions made by married couples (living in states that recognized their marriage) before June 2013 to decisions made by married couples (living in states that recognized their marriage) after June 2013. Before June 2013, such couples were treated as married under state law but not under federal law; this changed as a result of the Supreme Court decision in the Windsor case. This is a significant legal change, and it is an event that is largely independent of other social changes; therefore, it could be used to construct a credible natural experiment. Or, using contemporary data, researchers could compare couples who have formed civil unions or domestic partnerships, and thus are treated as "married" under state law but unmarried under most federal laws, to married same-sex couples.

Studies could also compare same-sex couples who have celebrated commitment ceremonies or private marriages but do not have a legal union to couples who have married. Such studies would help distinguish the symbolic and social significance of "marriage" from the legal rights it carries. At least one study has found that when same-sex couples marry, they typically identify legal rights as comparatively less important than marriage's personal or social meanings (Richman, 2010). In other studies, couples have suggested that legal rights are extremely important (Shulman, Gotta, \& Green, 2012). Moreover, even if couples self-report that legal rights are comparatively less significant, the incentives to specialize embedded in marriage law may nonetheless encourage particular patterns of labor allocation.

Comparisons of different-sex and same-sex married couples could be undertaken in other countries that have legalized marriage or created other formal legal status for same-sex couples (e.g., Badgett, 2009). There has been at least one study of this kind undertaken in the Netherlands, where same-sex marriage has been legal since 2001 - that study found that married same-sex couples had significantly higher levels of specialization than unmarried same-sex couples, though not as high as married different-sex couples (Jaspers \& Verbakel, 2013). Legal recognition of same-sex relationships is evolving quickly around the world, with many countries legalizing same-sex marriage (Pew Research, 2014). But in some countries, same-sex marriage may not include exactly the same rights as different-sex marriage. A particularly important variable to consider is the extent to which same-sex couples may adopt children. In the United States, married same-sex couples can generally jointly adopt children. Internationally, however, that is often not the case. At least as of 2011, several countries that permitted same-sex couples to marry did not permit them to jointly adopt (Saez, 2011).

Finally, cross-national comparisons of same-sex and/or different-sex couples could help isolate the importance of marriage rights. There is a growing body of cross-national work on labor allocation (e.g., Fuwa, 2004; Geist, 2005; Heisig, 2011). As in any work of this kind, it would be essential to consider and account for both "micro-level" factors, such as relative resources of spouses, and "macro-level" factors, such as the larger national context and social policy (Coltrane, 2010; Fuwa, 2004; Geist, 2005; Heisig, 2011; Treas \& Lui, 2013). Greater attention should also be given to the legal rights that come with marriage and the extent to which a country's social safety net provides benefits (e.g., health care, pension, and survivor's benefits) that American couples often receive through marriage. Other factors that would be especially important to consider include employment policies (e.g., maternity, paternity, and parental leave; limitations on hours or overtime; availability of part-time work) and existence or absence of public or subsidized child care.

Researchers exploring any of these comparisons within the United States, within other countries, or across countries would need to consider the myriad factors that could be confounding variables or that could work together with marriage to encourage specialization. These would include factors typically included in other studies on labor allocation, such as relative earnings, educational level, or time demands of a job. Other important factors include race, class, existence of children being raised by the couple, biological connection to children, legal relation to children, and age of children. It would also be important to consider the age of the spouses and the length of time (if any) that they cohabited prior to marrying. Same-sex couples may be, on average, older, and in "older relationships," than different-sex couples when they marry, since many same-sex couples who marry have been living together-and sometimes raising children together-for an extended 
period of time before legal change permitted them to marry.

Moreover, there has long been debate within the LGBT community regarding whether marriage, with its patriarchal and exclusionary history, is normatively desirable; as litigation and lobbying efforts to expand marriage equality began to bear fruit, these internal debates continued, even as many celebrated the extent to which providing access to marriage was an important step forward in gay and lesbian equality more generally (e.g., Lannutti, 2005; Widiss, 2012). Even now that same-sex marriage rights are universal in the United States, some same-sex couples who have made long-term commitments to each other may nonetheless eschew marriage. (Of course, some committed different-sex couples make the same choice.) The opposite may also be true. Some same-sex couples may marry precisely because it offers the opportunity to disrupt the heteronormative assumptions of traditional marriage. Indeed, as plaintiffs in the first marriage equality cases - unsuccessful bids for marriage back in the early 1970s-expressed it, same-sex marriage offers the opportunity to "challenge mainstream definitions of marriage" and to "turn the whole institution of marriage upside down" (Widiss, 2012, pp. 771-772). Studies that incorporate interviews, diary data, or other more qualitative assessments could help give a fuller picture of how these factors might affect choices regarding whether to marry and how to allocate household labor responsibilities.

\section{CONCLUSION}

The rapid expansion of marriage rights in the United States offers exciting new opportunities for developing models that test the significance of marriage relative to gender in the household labor allocation choices that (same-sex and different-sex) couples make. Now that marriage rights are universal in this country, same-sex married couples are directly comparable to different-sex couples. Analysis of historical data or longitudinal studies, however, still requires careful assessment of the distinct bundles of legal rights that were available when the data were collected. Additionally, as outlined in the previous section, the past state-based variability offers the opportunity to disaggregate distinct aspects of state marriage law, federal marriage law, and the personal and societal meanings of marriage. Because there are so many different moving parts, it would be quite labor intensive to develop a single instrument that maps precisely which rights were available in all 50 states at all points over the past 10 years. My hope, however, is that social scientists and legal scholars will collaborate to develop survey instruments and other research designs that accurately capture the complexity of legal recognition and that are appropriately tailored to the relevant data and the researchers' objectives.

It is, of course, impossible to know what future studies will find; there are, however, two general possibilities. It could be that same-sex couples, notwithstanding marriage, continue to share child-care and domestic responsibilities more equally than different-sex couples. This would suggest that gender norms and/or sex-based preferences are comparatively more important than marriage in the persistence of a gendered labor allocation for different-sex married couples. Or it could be that studies will reveal that, over time, as they enjoy more of the benefits of marriage and with it the incentives of marriage to specialize, same-sex married couples, particularly couples raising children together, will demonstrate levels of specialization that are typical of different-sex married couples. This would suggest that marriage law, along with societal and personal understandings of what marriage means, play a far larger role in the choices couples make than is typically understood.

Research along these lines could be important for policy design, for both same-sex and different-sex couples. For example, in many states, judges are often extremely reluctant to award alimony or maintenance to dependent spouses upon divorce. Since family law no longer mandates that women take on primary caretaking responsibilities, it is common for judges to characterize dropping out of or minimizing labor market participation as an "individual" choice or the result of gender norms outside the reach of the law, and accordingly conclude that a dependent spouse (in different-sex couples, typically the wife) must bear the consequences of that choice. Findings that marriage itself, even among same-sex couples, encourages specialization could change the conversation dramatically. Such findings could call for rethinking the many aspects of marriage law that encourage specialization, as well as the workplace laws that make it difficult to share domestic responsibilities-and for 
building more robust protections for dependent spouses (men or women, in gay or straight marriages) who take on primary caretaking roles.

\section{Author's Note}

I thank Joni Hersch, Ramona Oswald, Charlotte Patterson, Kimberly Richman, Suzanna Walters, participants in the 2014 Work and Family Researchers Network conference, the anonymous reviewers, and most especially Brian Powell, for their very helpful suggestions.

\section{REFERENCES}

Acs, G., \& Maag, E. (2005). Irreconcilable differences? The conflict between marriage promotion initiatives for cohabiting couples with children and marriage penalties in tax and transfer programs. National Survey of America's Families. Washington, DC: Urban Institute.

Albiston, C. (2009). Institutional inequality. Wisconsin Law Review, 1093-1167.

Antecol, H., \& Steinberger, M. (2011). Labor supply differences between married heterosexual women and partnered lesbians. Economic Inquiry, 51, 783-805.

Badgett, M. V. L. (2001). Money, myths, and change: The economic lives of lesbians and gay men. Chicago, IL: University of Chicago Press.

Badgett, M. V. L. (2009). When gay people get married: What happens when societies legalize same-sex marriage. New York, NY: New York University Press.

Bar, M., \& Leukhina O. (2009). To work or not to work: Did tax reforms affect labor force participation of married couples? B. E. Journal of Macroeconomics, 9, 1-28.

Bargain, O., Gonzalez, L., Keane, C., \& Ozcan, B. (2012). Female labor supply and divorce: New evidence from Ireland. European Economic Review, 56, 1675-1691.

Batalova, J. A., \& Cohen P. N. (2002). Premarital cohabitation and housework: Couples in cross-national perspectives. Journal of Marriage and Family, 64, 743-755.

Baxter, J. (2005). To marry or not to marry: Marital status and the household division of labor. Journal of Family Issues, 26, 300-321.

Belkin, L. (2009, November 8). The way we live now: What's good for the kids. New York Times Magazine, MM9.

Berkowitz, D. (2011). Maternal instincts, biological clocks, and soccer moms: Gay men's parenting and family narratives, Symbolic Interaction, 34, 514-535.

Bianchi, S. M., Robinson, J. P., \& Milkie, M. A. (2006). Changing rhythms of American family life. New York, NY: Russell Sage Foundation.
Biblarz, T. J., \& Savci E. (2010). Lesbian, gay, bisexual, and transgender families. Journal of Marriage and Family, 72, 480-497.

Bittman, M., England, P., Sayer, L., Folbre, N., \& Matheson, G. (2003). When does gender trump money? Bargaining and time in household work. American Journal of Sociology, 109, 186-214.

Bowman, C. G. (2004). Legal treatment of cohabitation in the United States. Law and Policy, 26, 119-151.

Brines, J. (1994). Economic dependency, gender, and the division of labor at home. American Journal of Sociology, 100, 652-688.

Brines, J., \& Joyner, K. (1999). The ties that bind: Principles of cohesion in cohabitation and marriage. American Sociological Review, 64, 333-355.

Budig, M. J., \& Hodges, M. J. (2010). Differences in disadvantage: Variation in the motherhood penalty across White women's earning distribution. American Sociological Review, 75, 705-728.

Carrington, C. (1999). No place like home: Relationships and family life among lesbians and gay men. Chicago, IL: University of Chicago Press.

Case, A. C., Lin, I., \& McLanahan, S. S. (2003). Explaining trends in child support: Economic, demographic, and policy effects. Demography, 40, 171-189.

Chan, R. W., Brooks, R. C., Raboy, B., \& Patterson, C. J. (1998). Division of labor among lesbian and heterosexual parents: Associations with children's adjustment. Journal of Family Psychology, $12,402-419$.

Cherlin, A. J. (2010). Demographic trends in the United States: A review of research in the 2000s. Journal of Marriage and Family, 72, 403-419.

Chiappori, P. A., Fortin, B., \& Lacroix, G. (2002). Marriage market, divorce legislation, and household labor supply. Journal of Political Economy, $110,37-72$.

Claffey, S. T., \& Mickelson, K. D. (2009). Division of household labor and distress: The role of perceived fairness for employed mothers. Sex Roles, 60, 819-830.

Coltrane, S. (2010). Gender theory and household labor. Sex Roles, 63, 791-800.

Coltrane, S., \& Shih, K. Y. (2010). Gender and the division of labor. In J. C. Chrisler \& D. R. McCreary (Eds.), Handbook of gender research in psychology (pp. 401-422). New York, NY: Springer.

Downing, J. B., \& Goldberg, A. E. (2011). Lesbian mothers' constructions of the division of paid and unpaid labor. Feminism and Psychology, 21, $100-120$.

Edin, K. (2000). What do low-income single mothers say about marriage. Social Problems, 47, 112-130.

Edin, K., \& Kefalas, M. (2005). Promises I can keep: Why poor women put motherhood before 
marriage. Berkeley, CA: University of California Press.

Edin, K., \& Lein, L. (1997). Making ends meet: How single mothers survive welfare and low-wage work. New York, NY: Russell Sage Foundation.

Eissa, N., \& Hoynes, H. W. (2004). Taxes and the labor market participation of married couples: The Earned Income Tax Credit. Journal of Public Economics, 88, 1931-1958.

Evertsson, M., \& Nermo, M. (2004). Dependence within families and the division of labor: Comparing Sweden and the United States. Journal of Marriage and Family, 66, 1272-1296.

Figinski, T. F. (2011). Women and the Social Security earnings test. Unpublished manuscript, University of California, Irvine. Retrieved from ssrn.com/abstract_1821290

Fine, M. A., \& Fine, D. R. (1994). An examination and evaluation of recent changes in divorce laws in five Western countries: The critical role of values. Journal of Marriage and Family, 56, 249-263.

Fisher, H. (2013). The effect of marriage tax penalties and subsidies on marital status. Fiscal Studies, 34, 437-465.

Fuwa, M. (2004). Macro-level gender inequality and the division of household labor in 22 countries. American Sociological Review, 69, 751-767.

Gabb, J. (2005). Lesbian m/otherhood: Strategies of familial-linguistic management in lesbian parent-families, Sociology, 39, 583-603.

Gates, G. J. (2010). Same-sex couples in US Census Bureau data: Who gets counted and why. Los Angeles, CA: Williams Institute. Retrieved from http://williamsinstitute.law.ucla.edu/wp-content/ uploads/Gates-Who-Gets-Counted-Aug-2010.pdf

Gates, G. J. (2011). Family formation and raising children among same-sex couples. Family Focus on LGBT Families, FF-51.

Gates, G. J. (2013a). Brief amicus curiae of Gary J. Gates, United States v. Windsor, No. 12-307.

Gates, G. J. (2013b). LGBT parenting in the United States. Los Angeles, CA: Williams Institute. Retrieved from http://williamsinstitute. law.ucla.edu/research/census-lgbt-demographicsstudies/lgbt-parenting-in-the-united-states/

Gates, G. J., \& Newport, F. (2015). An estimated 780,000 Americans in same-sex marriages. Retrieved from http://www.gallup.com/ poll/182837/estimated-780-000-americans-sexmarriages.aspx

Geist, C. (2005). The welfare state and the home: Regime differences in the domestic division of labor. European Sociological Review, 21, 23-41.

Gerson, K. (2010). The unfinished revolution: How a new generation is reshaping family, work, and gender in America. New York, NY: Oxford University Press.

Gibson-Davis, C. M. (2007). Expectations and the economic bar to marriage among low-income couples. In P. England \& K. Edin (Eds.), Unmarried couples with children (pp. 84-103). New York, NY: Russell Sage Foundation.

Glauber, R. (2007). Marriage and the motherhood penalty among African Americans, Hispanics, and Whites. Journal of Marriage and Family, 69, 951-961.

Glauber, R., \& Gozjolko, K. (2011). Do traditional fathers always work more? Gender ideology, race, and parenthood. Journal of Marriage and Family, 73, 1133-1148.

Goldberg, A. E. (2010). Lesbian and gay parents and their children. Washington, DC: American Psychological Association.

Goldberg, A. E. (2012). Gay dads: Transitions to adoptive fatherhood. New York, NY: New York University Press.

Goldberg, A. E. (2013). "Doing" and "undoing" gender: The meaning and division of housework in same-sex couples. Journal of Family Theory and Review, 5, 85-104.

Goldberg, A. E., \& Gartrell, N. K. (2014). LGB-parent families: The current state of the research and directions for the future. Advances in Child Development and Behavior, 46, 57-88.

Goldberg, A. E., \& Perry-Jenkins, M. (2004). Division of labor and working-class women's well-being across the transition to parenthood. Journal of Family Psychology, 18, 225-236.

Goldberg, A. E., \& Perry-Jenkins, M. (2007). The division of labor and perceptions of parental roles: Lesbian couples across the transition to parenthood. Journal of Social and Personal Relationships, 24, 297-318.

Goldberg, A. E., Smith, J. Z., \& Perry-Jenkins, M. (2012). The division of labor in lesbian, gay, and heterosexual new adoptive parents. Journal of Marriage and Family, 74, 812-828.

Gray, J. S. (1998). Divorce-law changes, household bargaining, and married women's labor supply. American Economic Review, 88, 628-642.

Greenstein, T. N. (2000). Economic dependence, gender, and the division of labor in the home: A replication and extension. Journal of Marriage and Family, 62, 322-335.

Greenstein, T. N. (2009). National context, family satisfaction, and fairness in the division of household labor. Journal of Marriage and Family, 71, 1039-1051.

Gregory, J. D., Swisher, P. N., \& Wilson, R. F. (2005). Understanding family law. Newark, NJ: LexisNexis.

Grunow, D., Schulz, F., \& Blossfeld, H.-P. (2012). What determines change in the division of housework over the course of marriage? International Sociology, 1-19.

Gupta, S. (2006). Her money, her time: Women's earnings and their housework hours. Social Science Research, 35, 975-999. 
Gupta, S. (2007). Autonomy, dependence, or display? The relationship between married women's earnings and housework. Journal of Marriage and Family, 69, 399-417.

Heisig, J. P. (2011). Who does more housework: Rich or poor? A comparison of 33 countries. American Sociological Review, 76, 74-99.

Herbst, Chris M. (2011). The impact of the Earned Income Tax Credit on marriage and divorce: Evidence from flow data. Population Research Policy Review, 31, 101-128.

Ishii-Kuntz, M., \& Coltrane, S. (1992). Remarriage, stepparenting, and household labor. Journal of Family Issues, 13(2), 215-223.

Jaspers, E., \& Verbakel, E. (2013). The division of paid labor in same-sex couples in the Netherlands. Sex Roles, 68, 335-348.

Joslin, C. G. (2014). Leaving no (nonmarital) child behind (2014). Family Law Quarterly, 48, 495-514.

Keane, M. P. (2011). Labor supply and taxes: A survey. Journal of Economic Literature, 49, 961-1075.

Killewald, A. (2013). A reconsideration of the fatherhood premium: Marriage, coresidence, biology, and wages. American Sociological Review, 78, 96-116.

Killewald, A., \& Gough, M. (2010). Money isn't everything: Wives' earnings and housework time. Social Science Research, 39, 987-1003.

Kurdek, L. A. (2007). The allocation of household labor by partners in gay and lesbian couples. Journal of Family Issues, 28, 132-148.

Lachance-Grzela, M., \& Bouchard, G. (2010). Why do women do the lion's share of housework? A decade of research. Sex Roles, 63, 767-780.

Lannutti, P. J. (2005). For better or worse: Exploring the meanings of same-sex marriage within the lesbian, gay, bisexual and transgendered community. Journal of Social and Personal Relationships, 22, 5-18.

Martin, P. W. (2012). The case for reforming the program's spouse benefits while "saving Social Security." Unpublished manuscript, Cornell Law School, Cornell University, Ithaca, NY. Retrieved from http://papers.ssrn.com/ sol3/papers.cfm?abstract_id=2183949

Matouschek, N., \& Rasul, I. (2008). The economics of the marriage contract: Theories and evidence. Journal of Law and Economics, 51, 59-110.

McCaffery, E. J. (1997). Taxing women. Chicago, IL: University of Chicago Press.

McMahon, S. H. (2011). To have and to hold: What does love (of money) have to do with joint filing? Nevada Law Journal, 11, 718-758.

Monte, L. M. (2007). Blended but not the Bradys: Navigating unmarried multiple partner fertility. In P. England \& K. Edin (Eds.), Unmarried couples with children (pp. 183-203). New York, NY: Russell Sage Foundation.

Moore, M. R. (2008). Gendered power relationships among women: A study of household decision making in Black, lesbian stepfamilies. American Sociological Review, 73, 335-356.

Moore, M. R., \& Stambolis-Ruhstorfer, M. (2013). LGBT sexuality and families at the start of the twenty-first century. Annual Sociology Review, 39, 491-507.

Mundy, L. (2013, May 22). The gay guide to wedded bliss. Atlantic Monthly. Retrieved from http:// www.theatlantic.com/magazine/archive/2013/06/ the-gay-guide-to-wedded-bliss/309317/

NeJaime, D. (2014). Parenthood before and after marriage. Unpublished manuscript, on file with author.

Noonan, M. (2013). The impact of social policy on the gendered division of housework. Journal of Family Theory \& Review, 5, 124-134.

Obergefell v. Hodges, 135 S. Ct. 2584 (2015).

Oldham, J. T. (2008). Changes in the economic consequences of divorces, 1958-2008. Family Law Quarterly, 42, 419-448.

Oswald, R. F., \& Kuvalanka, K. A. (2008). Same-sex couples: Legal complexities. Journal of Family Issues, 29, 1051-1066.

Parker-Pope, T. (2008, June 10). Gay unions shed light on gender in marriage. New York Times, F1.

Patterson, C. J. (1995). Families of the lesbian baby boom: Parents' division of labor and children's adjustment. Development Psychology, 31, $115-123$.

Patterson, C. J. (2000). Family relationships of lesbians and gay men. Journal of Marriage and Family, 62, 1052-1069.

Patterson, C. J., Sutfin, E. L., \& Fulcher, M. (2004). Division of labor among lesbian and heterosexual parenting couples: Correlates of specialized versus shared patterns. Journal of Adult Development, 11, 179-189.

Peplau, L. A., \& Fingerhut, A. W. (2007). The close relationships of lesbians and gay men. Annual Review of Psychology, 58, 405-424.

Perry-Jenkins, M., \& Folk, K. (1994). Class, couples, and conflict: Effects of the division of labor on assessments of marriage in dual-earner families. Journal of Marriage and Family, 56, 165-180.

Perry-Jenkins, M., Newkirk, K, \& Ghunney, A. K. (2013). Family work through time and space: An ecological perspective. Journal of Family Theory \& Review, 5, 105-123.

Pew Research. (2014). Gay marriage around the world [Fact sheet]. Retrieved from http://www. pewforum.org/2013/12/19/gay-marriage-aroundthe-world-2013/

Poortman, A., \& Mills, M. (2012). Investments in marriage and cohabitation: The role of legal and interpersonal commitment. Journal of Marriage and Family, 74, 357-376. 
Richman, K. D. (2010). By any other name: The social and legal stakes for same-sex marriage. University of San Francisco Law Review, 45, 357.

Saez, M. (2011). Same-sex marriage, same-sex cohabitation, and same-sex families around the world: Why "same" is so different. American University Journal of Gender, Social Policy and the Law, 19, 1-56.

Sanchez, L., \& Thomson, E. 1997. Becoming mothers and fathers: Parenthood, gender and the division of labor. Gender and Society, 11, 747-772.

Sayer, L. C., \& Fine, L. (2011). Racial-ethnic differences in U.S. married women's and men's housework. Social Indicators Research, 101, 259-265.

Shafer, E. F. (2011). Wives' relative wages, husbands paid work hours, and wives' labor-force exit. Journal of Marriage and Family, 73, 250-263.

Shulman, J. L., Gotta, G., \& Green, R. (2012). Will marriage matter? Effects of marriage anticipated by same-sex couples. Journal of Family Issues, 33, $158-181$.

Singley, S. G., \& Hynes, K. (2005). Transitions to parenthood: Work-family policies, gender, and the couple context. Gender and Society, 19, 376-397.

Solomon, S. E., Rothblum, E. D., \& Balsam, K. F. (2005). Money, housework, sex, and conflict: Same-sex couples in civil unions, those not in civil unions, and heterosexual married siblings. Sex Roles, 52, 561-575.

Soons, J. P. M., \& Kalmijn, M. (2009). Is marriage more than cohabitation? Well-being differences in 30 European countries. Journal of Marriage and Family, 71, 1141-1157.

Steuerle, C. E., \& Quakenbush, C. (2012). Social Security and Medicare taxes and benefits over a lifetime, 2012 update. Washington, DC: Urban Institute.

Stevenson, B. (2007). The impact of divorce laws on marriage-specific capital. Journal of Labor Economics, 25, 75-94.

Stevenson, B. (2008). Divorce law and women's labor supply. Journal of Empirical Legal Studies, 5, 853-873.

Sullivan, M. (2004). The family of women: Lesbian mothers, their children, and the undoing of gender. Berkeley, CA: University of California Press.

Sullivan, O. (1997) The division of housework among "remarried" couples. Journal of Family Issues, 18(2), 205-223.

Sullivan, O. (2011). An end to gender display through the performance of housework? A review and reassessment of the quantitative literature using insights from the qualitative literature. Journal of Family Theory \& Review, 3, 1-13.

Sullivan, O. (2013). What do we learn about gender by analyzing housework separately from child care? Some considerations from time-use evidence. Journal of Family Theory \& Review, 5, 72-84.

Thebaud, S. (2010). Masculinity, bargaining, and breadwinning: Understanding men's housework in the cultural context of paid work. Gender and Society, 24, 330-354.

Treas, J., \& Lui, J. (2013). Studying housework across nations. Journal of Family Theory \& Review, 5, 135-149.

United States v. Windsor, 133 S. Ct. 2675 (2013).

US Bureau of Labor Statistics. (2013). Women in the labor force: A databook (BLS Report 1049). Washington, DC: Author.

US Centers for Disease Control and Prevention. (2013). Unmarried childbearing FastStats. Washington, DC: Author. Retrieved from http://www. cdc.gov/nchs/fastats/unmarried-childbearing.htm

Usdansky, M. L., \& Parker, W. M. (2011). How money matters: College, motherhood, earnings, and wives' housework. Journal of Family Issues, 32, 1449-1473.

US Department of Labor. (2013). Guidance to employee benefit plans on the definition of "spouse" and "marriage" under ERISA and the Supreme Court's decision in United States v. Windsor (Technical Release No. 2013-04). Washington, DC: Author. Retrieved from http://www.dol.gov/ebsa/newsroom/tr13-04.html

US Department of the Treasury. (2013) All legal same-sex marriages will be recognized for federal tax purposes. Washington, DC: Author. Retrieved from http://www.treasury. gov/press-center/press-releases/Pages/j12153.aspx

US General Accounting Office. (2004). Defense of Marriage Act: Update to prior report (GAO-04-353R). Washington, DC: Author. Retrieved from http://www.gao.gov/new.items/ d04353r.pdf

US Social Security Administration. (2014). Windsor same-sex marriage claims. Washington, DC: Author. Retrieved from https://secure.ssa.gov/ apps10/public/reference.nsf/links/0620201402 4025PM

Widiss, D. A. (2012) Changing the marriage equation. Washington University Law Review, 89, 721-794.

Widiss, D. A. (2014). Leveling up after DOMA. Indiana Law Journal, 89, 43-65.

Widiss, D. A., \& Koppelman, A. (2015). A marriage by any other name: Why civil unions should receive federal recognition. Indiana Journal of Law and Social Equality, 3, 56-73.

Williams, J. (2000). Unbending gender: Why family and work conflict and what to do about it. New York, NY: Oxford University Press.

Zatz, N. (2009). Revisiting the class-parity analysis of welfare work requirements. Social Services Review, 83, 313-350. 